Submitted, accepted and published by:

Chemical Engineering Research and Design 93 (2015) 736-746

http://dx.doi.org/10.1016/j.cherd.2014.07.001

\title{
Performance of a low-cost iron ore as an oxygen carrier for Chemical Looping Combustion of gaseous fuels
}

\author{
Miguel A. Pans, Pilar Gayán*, Luis F. de Diego, Francisco García-Labiano, \\ Alberto Abad and Juan Adánez. \\ Department of Energy and Environment, Instituto de Carboquímica (CSIC) \\ Miguel Luesma Castán 4, 50018 Zaragoza, Spain \\ Phone number: +34976 733977
}

Fax number: +34976733318 


\title{
Performance of a low-cost iron ore as an oxygen carrier for Chemical Looping Combustion of gaseous fuels
}

Miguel A. Pans, Pilar Gayán*, Luis F. de Diego, Francisco García-Labiano, Alberto Abad and Juan Adánez.

Department of Energy and Environment, Instituto de Carboquímica (CSIC)

Miguel Luesma Castán 4, 50018 Zaragoza, Spain

Phone number: +34976 733977

Fax number: +34976733 318

E-mail: pgayan@icb.csic.es

*Corresponding Author. Tel.: +34-976-733977; fax: +34-976-733318; E-mail address: pgayan@icb.csic.es (P. Gayán)

Keywords: Chemical Looping Combustion, $\mathrm{CO}_{2}$ Capture, Oxygen Carrier, Iron oxide

\begin{abstract}
This work evaluates the performance of an iron ore, mainly composed of $\mathrm{Fe}_{2} \mathrm{O}_{3}$, as an oxygen carrier (OC) for chemical looping combustion (CLC) with gaseous fuels. The OC was characterized by TGA and evaluated in a continuous $500 \mathrm{~W}_{\text {th }}$ CLC unit, using $\mathrm{CH}_{4}$, syngas and a PSA off-gas as fuels. The OC was able to fully convert syngas at $880^{\circ} \mathrm{C}$. However, lower conversion rates were observed with methane-containing fuels. The addition of a Ni-based OC was evaluated in order to increase the reactivity of the
\end{abstract}


OC with methane. In spite of this, an absence of catalytic effect was observed for the Ni-based OC. A deep analysis was carried out into the reasons for the absence of catalytic effect of the Ni-based OC. The performance of the iron ore with regard to attrition and fluidization behaviour was satisfactory throughout 50 hours of hot operation in the continuous CLC plant. Thus, this low cost material is a suitable OC for gaseous fuels mainly composed of $\mathrm{H}_{2}$ and $\mathrm{CO}$.

\section{Introduction}

Since the late 19th century there has been an increase in the average temperature of Earth's atmosphere and oceans primarily as the result of anthropogenic emissions that have intensified the natural greenhouse effect, causing global warming. About one third of global $\mathrm{CO}_{2}$ emissions come from the burning of fossil fuels in power generation. One of the options to overcome the anthropogenic greenhouse effect is the development of $\mathrm{CO}_{2}$ capture and storage (CCS) technologies (IPPC, 2005). Among the different CCS technologies currently under development, Chemical Looping Combustion (CLC) has been suggested as one of the most promising.

CLC is a novel combustion technology with inherent separation of the greenhouse gas $\mathrm{CO}_{2}$ that involves the use of an oxygen carrier to transfer oxygen from air to the fuel, preventing direct contact between them. Fig. 1 shows a general scheme of the CLC process. A CLC system is comprised of two interconnected reactors, designated as air and fuel reactors, respectively. Inside the fuel reactor, the fuel gas $\left(\mathrm{C}_{n} \mathrm{H}_{2 m}\right)$ is oxidized to $\mathrm{CO}_{2}$ and $\mathrm{H}_{2} \mathrm{O}$ by a metal oxide $(\mathrm{MeO})$, which is reduced to a metal $(\mathrm{Me})$ or a reduced form of $\mathrm{MeO}$ :

$(2 n+m) \mathrm{Me}_{\mathrm{x}} \mathrm{O}_{\mathrm{y}}+\mathrm{C}_{\mathrm{n}} \mathrm{H}_{2 \mathrm{~m}} \rightarrow(2 \mathrm{n}+\mathrm{m}) \mathrm{Me}_{\mathrm{x}} \mathrm{O}_{\mathrm{y}-1}+\mathrm{nCO}_{2}+\mathrm{m} \mathrm{H}_{2} \mathrm{O}$ 
The reduced oxide is subsequently transferred to the air reactor, where it is oxidized with air, leaving the regenerated material ready to start a new cycle:

$$
\mathrm{Me}_{\mathrm{x}} \mathrm{O}_{\mathrm{y}-1}+1 / 2 \mathrm{O}_{2} \rightarrow \mathrm{Me}_{\mathrm{x}} \mathrm{O}_{\mathrm{y}}
$$

Thus, fuel combustion is split into two reactions, which are carried out in the air and fuel reactors. The total heat produced in the system is the same as in normal combustion with air, but with the benefit of inherent $\mathrm{CO}_{2}$ separation in the flue gases. The flue gas exiting the air reactor contains only $\mathrm{N}_{2}$ and unreacted $\mathrm{O}_{2}$. The exit gas from the fuel reactor contains only $\mathrm{CO}_{2}$ and $\mathrm{H}_{2} \mathrm{O}$. After water condensation, almost pure $\mathrm{CO}_{2}$ can be obtained with little energy lost for component separation.

An important key in the development of the CLC technology is the selection of an appropriate oxygen carrier for the CLC process. Usually, an oxygen carrier consists of a metal oxide supported on an inert material (Adanez et al., 2012). To develop an optimum oxygen carrier, synthetic particles based on a metal oxide and a support were prepared by means of several methods with high performance and stability (Gayan et al., 2009; Ishida et al., 2002; Mattisson et al., 2006).

Adánez et al. (Adanez et al., 2009; Dueso et al., 2009) at ICB-CSIC in Spain tested the suitability of Ni-based oxygen carriers prepared by impregnation on $\alpha-\mathrm{Al}_{2} \mathrm{O}_{3}$ for methane and syngas combustion in a continuously operated $500 \mathrm{~W}_{\text {th }}$ CLC unit. At $880^{\circ} \mathrm{C}$, an oxygen carrier-to-fuel ratio higher than 1.5 and a solid inventory in the fuelreactor of $600 \mathrm{~kg}$ per $\mathrm{MW}_{\text {th }}$ were necessary to achieve combustion efficiencies close to the maximum allowed by the thermodynamic constraint. 
Johansson et al. (Johansson et al., 2006a) carried out different tests using syngas and natural gas as fuels in a continuous $300 \mathrm{~W}$ CLC system with a Ni-based OC, with very high conversion of the fuel and, therefore, high combustion efficiencies. The same facility was used by Abad et al. (Abad et al., 2006) to perform experiments using a Mnbased oxygen carrier and syngas as fuel for $70 \mathrm{~h}$ with high efficiencies at temperatures in the range $800-950^{\circ} \mathrm{C}$.

Abad et al (Abad et al., 2007c) used an oxygen-carrier of 60 wt $\% \mathrm{Fe}_{2} \mathrm{O}_{3}$ with $\mathrm{Al}_{2} \mathrm{O}_{3}$ as a support, prepared by freeze granulation, in a $300 \mathrm{~W}_{\text {th }}$ continuous unit. Tests using natural gas or syngas as fuel were carried out at temperatures ranging from 800 to $950^{\circ} \mathrm{C}$ for a total of $40 \mathrm{~h}$ in combustion conditions. The combustion efficiency of syngas was high, about $99 \%$ for all experimental conditions. However, efficiencies for methane combustion ranged up to $94 \%$. Gayan et al. (Gayan et al., 2012) used a synthetic Febased oxygen carrier, produced by incipient impregnation on $\gamma-\mathrm{Al}_{2} \mathrm{O}_{3}$, in a continuous CLC unit to burn a simulated PSA off-gas and methane as fuels, for $46 \mathrm{~h}$. An oxygen carrier to fuel ratio of $>1.5$ was needed to achieve full combustion efficiencies at $880^{\circ} \mathrm{C}$. The solids inventory needed to achieve full combustion of the fuel was around $500 \mathrm{~kg} / \mathrm{MW}_{\text {th }}$ at $880^{\circ} \mathrm{C}$, which corresponds to an Fe inventory of $50 \mathrm{~kg} / \mathrm{MW}_{\text {th }}$. This metal inventory was the lowest one found when working with Fe-based materials.

Another route for $\mathrm{OC}$ development is to find low-cost and environmental friendly materials with suitable properties that allow them to work as oxygen carriers. Minerals, ores and industrial residues or by-products are good choices for this purpose. Our research group has been analysing the behaviour of residues as oxygen carriers. Mendiara et al. (Mendiara et al., 2012a) conducted a study on the reactivity of an iron waste material from aluminium manufacture with different gases by means of thermogravimetric analysis (TGA) and a batch fluidized bed reactor (FB). TGA 
experiments showed that the bauxite waste samples reacted more rapidly with $\mathrm{H}_{2}$ than with $\mathrm{CO}$ and $\mathrm{CH}_{4}$. Batch $\mathrm{FB}$ experiments resulted in $\mathrm{H}_{2}$ and $\mathrm{CO}$ being completely converted. $\mathrm{CH}_{4}$ was partially converted at all temperatures and reducing times tested. The same material was tested by Ortiz et al. (Ortiz et al., 2011) as an oxygen carrier in a $500 \mathrm{~W}_{\text {th }}$ CLC unit to burn different kinds of gas fuels such as a simulated PSA tail gas, syngas and $\mathrm{CH}_{4}$. The $\mathrm{OC}$ showed high enough oxygen transport capacity and reactivity to fully convert syngas at $1153 \mathrm{~K}$. The high combustion efficiencies achieved with $\mathrm{CO}$ and $\mathrm{H}_{2}$ were comparable to those obtained in the same conditions using a highly reactive synthetic Fe-based material (Mendiara et al., 2012b). Song et al. (Song et al., 2008) conducted several experiments with calcium sulfate as a novel oxygen carrier, using $\mathrm{CH}_{4}$ as fuel. The results showed that this novel oxygen carrier had high reduction reactivity and stability in a long-term reduction-oxidation (redox) test.

Another low-cost option is the use of minerals as oxygen carriers. Ilmenite has been studied as a possible oxygen carrier for CLC with gaseous fuels (Azis et al., 2010; Cuadrat et al., 2009; Leion et al., 2008; Liu et al., 2013; Mendiara et al., 2014; Proll et al., 2009). The material showed adequate reactivity when working with syngas as fuel, but the conversion achieved when working with $\mathrm{CH}_{4}$ as fuel was relatively low.

As shown by the above, high reactivities could be achieved with iron minerals or iron waste products from industry when using $\mathrm{CO}$ and/or $\mathrm{H}_{2}$ as fuels, the main drawback of these materials being their low reactivity with $\mathrm{CH}_{4}$. However, Ryden et al. (Ryden et al., 2009) achieved high methane conversion by mixing $\mathrm{Fe}_{2} \mathrm{O}_{3}$-containing waste materials from the steel industry with $5 \mathrm{wt} \% \mathrm{NiO}$-based particles. Similar results were found by the same authors using ilmenite as an oxygen carrier (Ryden et al., 2010b). An increase in combustion efficiency by a factor of 3 was observed when adding $5 \mathrm{wt} \%$ NiO-based particles to the ilmenite bed in a batch fluidized bed reactor, using $\mathrm{CH}_{4}$ as fuel. By 
working in a small circulating fluidized bed reactor, the addition of a small amount of $\mathrm{NiO}(\approx 1$ wt. $\%)$ increased the conversion of the fuel considerably.

The aim of this work is to analyse the behaviour of a natural mineral sourced from a haematite mine, mainly composed of $\mathrm{Fe}_{2} \mathrm{O}_{3}$, as an oxygen carrier for use in a CLC process using gaseous fuels. Particle reactivity was evaluated by TGA. The behaviour of the oxygen carrier with respect to gas combustion was studied in continuous operation in a $500 \mathrm{~W}_{\text {th }}$ CLC prototype using $\mathrm{CH}_{4}$, syngas and a PSA off-gas. The effect on the combustion efficiency of the operating conditions, such as the oxygen carrier-to-fuel ratio and fuel reactor temperature was also determined in the continuous unit. Moreover, the effect of $\mathrm{Ni}$ addition on the methane conversion was also evaluated in the continuous unit.

\section{Experimental section}

\subsection{Oxygen carrier materials}

A mineral from a haematite mine in Tierga (Spain) was tested. It was crushed and sieved to the desired size $(100-300 \mu \mathrm{m})$.

A Ni-based OC was prepared over $\alpha-\mathrm{Al}_{2} \mathrm{O}_{3}$ (obtained by calcination of $\gamma-\mathrm{Al}_{2} \mathrm{O}_{3}$ at $1150^{\circ} \mathrm{C}$ for 2 hours) particles of $0.1-0.32 \mathrm{~mm}$ with density of $2.0 \mathrm{~g} / \mathrm{cm}^{3}$ and porosities of $47.3 \%$ respectively. The details of the preparation of the Ni-based OC have been described elsewhere (Adanez et al., 2009).

Several techniques were used to physically and chemically characterize the fresh and post-use oxygen carrier particles. The composition of the oxygen carrier was determined by inductively coupled plasma atomic emission spectrometry (ICP-AES) (Jobin Ybon 
2000 apparatus). The identification of crystalline chemical species was performed by powder X-ray diffraction (XRD) patterns acquired in a Bruker AXS D8ADVANCEXray diffractometer using $\mathrm{Ni}$-filtered $\mathrm{Cu} \mathrm{K} \alpha$ radiation equipped with a graphite monochromator. The force needed to fracture a particle was determined using a Shimpo FGN-5X crushing strength apparatus. Mechanical strength was taken as the average value of at least 20 measurements. The pore volume was measured by $\mathrm{Hg}$ intrusion in a Quantachrome PoreMaster 33, whereas the skeletal density of the particles was measured with a Micromeritics AccuPyc II 1340 helium picnometer. The surface area of the oxygen carrier was determined by the Brunauer-Emmett-Teller (BET) method through the adsorption/desorption of nitrogen at $77 \mathrm{~K}$ in a Micro-meritics ASAP-2020 (Micromeritics Instruments Inc.).

Both fresh and used solids were chemically and physically characterized by means of the different techniques described above in continuous CLC operation samples, in order to identify the possible changes that could take place in a solid after its use in continuous operation.

Table 1 shows the mineral composition determined by ICP-AES. The main physical and chemical properties of the OCs are shown in Table 2. The main solid phases of the haematite mineral, identified by XRD diffraction, were haematite $\left(\mathrm{Fe}_{2} \mathrm{O}_{3}\right)$, dolomite $\left(\mathrm{CaMg}\left(\mathrm{CO}_{3}\right)_{2}\right)$, and $\mathrm{SiO}_{2}$. The mineral was calcined at $950^{\circ} \mathrm{C}$ for $12 \mathrm{~h}$, in order to decompose the dolomite impurities present in the sample to $\mathrm{CaO}$ and $\mathrm{MgO}$, and to increase its mechanical strength.

Oxygen transport capacity, $R_{O C}$, is defined as the mass fraction of the oxygen carrier that can be used in oxygen transfer:

$$
R_{O C}=\frac{m_{o}-m_{r}}{m_{o}}
$$


where $m_{o}$ and $m_{r}$ are the mass of fully oxidized and reduced sample, respectively. The value of $R_{O C}$ depends on the final oxidation state after reduction. Only the transformation from haematite $\left(\mathrm{Fe}_{2} \mathrm{O}_{3}\right)$ to magnetite $\left(\mathrm{Fe}_{3} \mathrm{O}_{4}\right)$ may be applicable for industrial CLC systems, owing to thermodynamic limitations. Further reduction to wustite $(\mathrm{FeO})$ or Fe would increase the equilibrium concentrations of $\mathrm{CO}$ and $\mathrm{H}_{2}$ (Abad et al., 2007b) by decreasing the $\mathrm{CO}_{2}$ purity obtained in the fuel reactor. Moreover, a number of authors found agglomeration problems in the bed associated with the oxidation of wustite in air (Cho et al., 2006; Ryden et al., 2010a). Thus, reduction to $\mathrm{FeO}$ or Fe should be prevented in a CLC system.

The active $\mathrm{Fe}_{2} \mathrm{O}_{3}$ content of the OC was 76 wt. $\%$, calculated by TGA using 15 vo. $\% \mathrm{H}_{2}$ at $950^{\circ} \mathrm{C}$, assuming reduction to $\mathrm{Fe}$. This $\mathrm{Fe}_{2} \mathrm{O}_{3}$ content corresponded to an oxygen transport capacity of $2.54 \%$, calculated by assuming that $\mathrm{Fe}_{2} \mathrm{O}_{3}$ is reduced to $\mathrm{Fe}_{3} \mathrm{O}_{4}$. As can be observed comparing Tables 1 and 2, the $\mathrm{Fe}_{2} \mathrm{O}_{3}$ concentration determined by ICPAES was different from the one obtained by TGA. The percentage determined by ICPAES corresponded to the total amount of $\mathrm{Fe}_{2} \mathrm{O}_{3}$ present in the mineral and the $\mathrm{Fe}_{2} \mathrm{O}_{3}$ concentration determined by TGA corresponded to the amount of iron-reducible species, which were the species that would be used in the Chemical Looping Process. A high crushing strength value was obtained, which was adequate for fluidization operation.

\subsection{Reactivity tests by TGA}

The reactivity of the oxygen carrier was determined in a thermogravimetric analyser (CI electronics), described elsewhere (Adanez et al., 2004). For the experiments, the oxygen carrier was loaded in a platinum basket and heated to the set operating temperature in 
air atmosphere. After weight stabilization, the experiment was started by exposing the oxygen carrier to alternating reducing and oxidizing conditions. To prevent mixing of the combustible gas and air, nitrogen was introduced for two min after each reducing and oxidizing period.

The reactivity of the oxygen carrier was determined with different reducing gases: $\mathrm{CH}_{4}$, $\mathrm{CO}$ and $\mathrm{H}_{2}$ at different temperatures $\left(950\right.$ and $\left.830^{\circ} \mathrm{C}\right)$. The gas composition was 15 vol. $\%$ of the reducing gas. In the experiments with $\mathrm{CH}_{4}, 20$ vol, $\% \mathrm{H}_{2} \mathrm{O}$ was introduced to prevent carbon formation by methane decomposition. Steam was incorporated into the gas stream by bubbling it through a saturator containing water at the selected temperature to reach the desired water concentration. Similarly, $20 \mathrm{vol}, \% \mathrm{CO}_{2}$ was introduced together with $\mathrm{CO}$ to prevent carbon formation by the Boudouard reaction. In all cases, nitrogen was used to balance. 100 vol.\% air was used as the reacting gas for the oxidation reaction.

The conversion of solids for the reduction reaction was calculated as:

$X_{r}=\frac{m_{o x}-m}{R_{O C} m_{o x}}$

where $\mathrm{m}_{\mathrm{ox}}$ was the mass of the fully oxidized solids, $\mathrm{m}$ the instantaneous mass of the sample, and $R_{O C}$ the oxygen transport capacity of solids for the transformation between $\mathrm{Fe}_{2} \mathrm{O}_{3}$ and $\mathrm{Fe}_{3} \mathrm{O}_{4}$, given in Table 2. The conversion for the oxidation reaction was calculated as $X_{o}=1-X_{r}$

\subsection{Batch fluidized bed reactor}


Several redox cycles were carried out in a batch fluidized bed reactor with a mixture of mineral+Ni-based $\mathrm{OC}$, in order to discern the gas product distribution during the reaction. The experimental set-up has been described elsewhere (Gayan et al., 2012).

The tests were carried out at $950^{\circ} \mathrm{C}$ with an inlet superficial gas velocity into the reactor of $10 \mathrm{~cm} / \mathrm{s}$. The composition of the reducing gas was 25 vol. $\% \mathrm{CH}_{4}$ and $10 \mathrm{vol} . \% \mathrm{H}_{2} 0$. The fluidized bed was fed with $200 \mathrm{~g}$ of a mineral mixture +Ni-based OC, with 2 wt. $\%$ $\mathrm{NiO}$ and 64 wt. $\% \mathrm{Fe}_{2} \mathrm{O}_{3}$.

Back-mixing in the system, which was illustrated by transient changes in gas concentration during the first seconds of reaction, was considered in order to obtain the actual concentration of the gases in the bed. The correction was performed using a method of deconvolution that takes into account the gas residence time distribution in the system (Levenspiel, 1981).

\subsection{ICB-CSIC-g1 facility}

Fig. 2 shows a schematic diagram of the continuous atmospheric CLC facility used in this work, which was designed and built at Instituto de Carboquimica (CSIC). The pilot plant basically consisted of two interconnected fluidized bed reactors - the air and fuel reactors, a riser for solids transport from the air reactor (AR) to the fuel reactor (FR), a solids valve to control the flow rate of solids fed to the fuel reactor, a loop seal and a cyclone. This design allowed variation and control of the solids circulation flow rate between both reactors.

The FR consisted of a bubbling fluidized bed (0.052 $\mathrm{m}$ i.d.) with a bed height of $0.1 \mathrm{~m}$. The oxidation of the carrier took place in the AR, which consisted of a bubbling fluidized bed ( $0.05 \mathrm{~m}$ i.d.) with a bed height of $0.1 \mathrm{~m}$, followed by a riser of $0.02 \mathrm{~m}$ i.d. 
and $1 \mathrm{~m}$ height. The regeneration of the oxygen carrier took place in the dense bed part of the AR, allowing residence times high enough for the complete oxidation of the reduced carrier. The gas outlet streams of the FR and AR were drawn to respective online gas analysers to collect continuous gas composition data. $\mathrm{CH}_{4}, \mathrm{CO}, \mathrm{CO}_{2}$ were measured at the fuel reactor outlet via an NDIR analyser (Maihak S710) together with $\mathrm{H}_{2}$ using a thermal conductivity analyser (Maihak S710). $\mathrm{CO}$ and $\mathrm{CO}_{2}$ were measured at the air reactor outlet by an NDIR analyser (Siemens/Ultramat 22P), and $\mathrm{O}_{2}$ was measured by a paramagnetic analyser (Siemens/Oxymat 5E). The experimental set up is described in detail elsewhere (Gayan et al., 2012).

The total solids inventory in the system was about $1.7 \mathrm{~kg}$ of solid material. The temperature in the air reactor was always kept constant at about $950^{\circ} \mathrm{C}$. The inlet flow of fuel was $0.3 \mathrm{Nm}^{3} / \mathrm{h}$, which corresponded to an inlet gas velocity in the fuel reactor of $0.17 \mathrm{~m} / \mathrm{s}$. The inlet air flow in the AR was $0.72 \mathrm{Nm}^{3} / \mathrm{h}$ as primary air, $(0.46 \mathrm{~m} / \mathrm{s}$ at $880^{\circ} \mathrm{C}$ ), and $0.15 \mathrm{Nm}^{3} / \mathrm{h}$ as secondary air. Nitrogen was used to fluidize the bottom loop seal $\left(0.0525 \mathrm{Nm}^{3} / \mathrm{h}\right)$.

Table 3 shows a summary of the different operating conditions used in the tests. Three different fuels were used during the experimental work: $\mathrm{CH}_{4}$, syngas and a simulated PSA off-gas. The composition of the simulated PSA off-gas fed to the FR was 12 vol.\% $\mathrm{CH}_{4}, 18$ vol.\% $\mathrm{CO}, 25$ vol. $\% \mathrm{H}_{2}$ and 45 vol. $\% \mathrm{CO}_{2}$. The syngas composition fed to the reactor for the different ratios was selected to fulfil the water-gas shift equilibrium (WGS) at the operating temperature, which was assumed to have been achieved immediately at the FR inlet. Two different $\mathrm{CO} / \mathrm{H}_{2}$ molar ratios (1 and 3) were also used, corresponding to typical gas compositions obtained in coal gasification processes. No steam was added to the fuel reactor in either of the experiments.

The oxygen carrier-to-fuel ratio $(\phi)$ was defined by Eq. (3), as: 


$$
\phi=\frac{F_{\mathrm{Fe}_{2} \mathrm{O}_{3}}}{b F_{\text {Fuel }}}
$$

where $F_{\mathrm{Fe}_{2} \mathrm{O}_{3}}$ was the molar flow rate of the iron oxide and $F_{\mathrm{Fuel}}$ was the inlet molar flow rate of the fuel in the FR. The parameter b was the stoichiometric coefficient of the fuel gas mixture, calculated in Eq. (4) as:

$$
b=\frac{4 x_{C_{4}}+x_{C O}+x_{H_{2}}}{x_{C_{4}}+x_{C O}+x_{H_{2}}}
$$

Thus, the oxygen carrier-to-fuel ratio $(\phi)$ was defined as the ratio between the oxygen supplied and the oxygen needed to stoichiometrically react with the fuel flow. A value of the $\phi$ ratio equal to unity meant that the oxygen supplied by the solids was exactly the stoichiometric oxygen to fully convert the fuel gas to $\mathrm{CO}_{2}$ and $\mathrm{H}_{2} \mathrm{O}$.

To analyse the effect of the $\phi$ ratio, experiments were carried out by varying the flow of fuel, but maintaining the solids circulation flow-rate roughly constant. The continuous atmospheric CLC facility used in this work was designed to allow the control of the solids flow rate fed to the fuel reactor independently of the fuel flow. Thus experiments were carried out by changing the fuel concentration but the gas velocity and solids circulation rates were maintained roughly constant. To maintain the total flow of fuel gas entering the fuel reactor, the corresponding flow of nitrogen was added in every case. When the flow $\mathrm{f}_{\mathrm{s}}$ varied, the air-to-fuel ratio, the solids inventory per $\mathrm{MW}_{\mathrm{th}}, m_{F R}^{*}$ and the gas concentration were varied simultaneously. The ratio of the constituent gases 
of the PSA off-gas, i.e. $\mathrm{CH}_{4}, \mathrm{H}_{2}, \mathrm{CO}, \mathrm{CO}_{2}$ was maintained constant under all operating conditions.

The effect of the fuel composition was evaluated working with $\mathrm{CH}_{4}$ and syngas. The effect of FR temperature on combustion efficiency was analysed using $\mathrm{CH}_{4}$ as fuel. Experiments M-1 to M-3 were performed at $830^{\circ} \mathrm{C}$; experiments $\mathrm{M}-4$ to $\mathrm{M}-6$ at $880^{\circ} \mathrm{C}$; and experiments $\mathrm{M}-7$ and $\mathrm{M}-8$ at $930^{\circ} \mathrm{C}$. The effect of the physical addition of a Nibased $\mathrm{OC}$ on combustion efficiency was analysed using $\mathrm{CH}_{4}$ as fuel (experiments M-9 and M-10).

Experiments PSA-1 to PSA-4 were conducted using a simulated PSA off-gas as fuel, at $880^{\circ} \mathrm{C}$, varying the oxygen carrier-to-fuel ratio.

Two different $\mathrm{CO} / \mathrm{H}_{2}$ molar ratios (1, experiments $\mathrm{S} 1$ to $\mathrm{S} 3$, and 3, experiments $\mathrm{S}-4$ to S-6) were also used when syngas was being used as fuel, corresponding to typical gas compositions obtained in coal gasification processes.

To evaluate the behaviour of the oxygen carrier during the combustion tests, combustion efficiency $\eta_{c}$, defined in Eq. (5), was used as a key parameter. Combustion efficiency $\left(\eta_{c}\right)$ was defined as the ratio of the oxygen consumed by the gas leaving the FR to that consumed by the gas when the fuel was completely burnt to $\mathrm{CO}_{2}$ and $\mathrm{H}_{2} \mathrm{O}$. The ratio therefore provided an idea about how close or far the CLC operation was from the full combustion of the fuel, i.e. $\eta_{c}=100 \%$.

$$
\eta_{\mathrm{c}}=\frac{\left(2 x_{\mathrm{CO}_{2}}+x_{\mathrm{CO}}+x_{\mathrm{H}_{2} \mathrm{O}}\right)_{\text {out }} \mathrm{F}_{\text {out }}-\left(2 x_{\mathrm{CO}_{2}}+x_{\mathrm{CO}}\right)_{\text {in }} F_{\text {in }}}{\left(4 x_{\mathrm{CH}_{4}}+x_{\mathrm{CO}}+x_{\mathrm{H}_{2}}\right)_{\text {in }} \mathrm{F}_{\text {in }}} 100
$$

where $F_{\text {in }}$ was the molar flow of the inlet gas stream, $F_{\text {out }}$ the molar flow of the outlet gas stream, and $\mathrm{x}_{\mathrm{i}}$ the molar fraction of the gas in the inlet or outlet gas stream. 
An increase in the reactivity of the $\mathrm{OC}$ with the number of redox cycles had been observed in previous works (Mendiara et al., 2012b). Consequently, the haematite mineral used in this work was firstly activated during the first hours of continuous operation, prior to the performing of the experiments. The activation process took place in the continuous unit, feeding $\mathrm{CH}_{4}$, at $880^{\circ} \mathrm{C}$ in the FR.

\section{Results and discussion}

\subsection{Reactivity by TGA}

The OC was first characterized by TGA, in order to discern its reactivity with different fuel gases $\left(\mathrm{CH}_{4}, \mathrm{H}_{2}\right.$ and $\left.\mathrm{CO}\right)$, since methane, syngas $\left(\mathrm{CO}+\mathrm{H}_{2}\right)$ and PSA off-gas (a mixture of $\mathrm{H}_{2}+\mathrm{CO}+\mathrm{CH}_{4}$ ) were used as fuel in the continuous unit. The influence of temperature was also studied.

For Fe-based oxygen carriers, different reduction reactions are possible depending on the reducing gas composition and temperature. For the data presented here, it was assumed that the weight variations observed in the TGA were mainly associated with the $\mathrm{Fe}_{2} \mathrm{O}_{3} / \mathrm{Fe}_{3} \mathrm{O}_{4}$ transformation. Fig. 3 shows the reduction and oxidation conversions versus time curves for the calcined mineral sample before activation, using $\mathrm{H}_{2}, \mathrm{CO}$ and $\mathrm{CH}_{4}$ as reacting gases, and air for the oxidation, at $950^{\circ} \mathrm{C}$. As can be seen, the oxygen carrier exhibited very rapid reduction and oxidation rates with $\mathrm{H}_{2}$ and $\mathrm{CO}$. However, the reactivity obtained with $\mathrm{CH}_{4}$ was considerably lower. These results agree with those obtained by Abad et al. (Abad et al., 2007a; Abad et al., 2007c), who determined that the reactivity of a synthetic iron-based oxygen carrier was higher using $\mathrm{H}_{2}$ or $\mathrm{CO}$ than that obtained with $\mathrm{CH}_{4}$ as a reducing gas. Moreover, Leion et al. (Leion et al., 2008) and Adánez et al. (Adanez et al., 2010) observed the same behaviour with ilmenite, a natural 
mineral mainly composed of iron and titanium, and Ortiz et al (Ortiz et al., 2011) using an iron waste material.

The effect of the temperature was tested by working at $830^{\circ} \mathrm{C}$. As can be seen in Fig. 3, no important effect was observed using $\mathrm{CO}$ and $\mathrm{H}_{2}$ as reacting gases, and fast conversion of the carrier was obtained anyway. However, in case where $\mathrm{CH}_{4}$ was used as the reacting gas, an important temperature effect was shown and the difference between the reactivities with $\mathrm{CO}$ and $\mathrm{H}_{2}$ and the reactivity with $\mathrm{CH}_{4}$ were more pronounced.

The reactivity of the oxygen carrier particles after activation in the CLC unit was also analysed by TGA, using $\mathrm{CH}_{4}$ as the reducing gas at $950^{\circ} \mathrm{C}$. Comparing the results achieved here with the results obtained with the calcined ones, a considerable increase in reactivity can be seen, for both the oxidation and reduction reactions, evidence of the activation of the sample.

\subsection{Test at ICB-CSIC-g1 facility}

A total of about $56 \mathrm{~h}$ at hot conditions, of which 50 corresponded to combustion conditions, were carried out at the facility using the Fe-based oxygen carrier. The effect of the oxygen carrier-to-fuel ratio, fuel reactor temperature and fuel composition on the combustion efficiency, $\eta_{c}$, was analysed. PSA off-gas, methane and syngas were used as fuel gases during the experimental tests.

The gas product concentrations from the fuel and air reactors were measured by on line analysers. These gas concentrations were used to make carbon, hydrogen and oxygen mass balances over the whole reactor system. For better comparison, the results are presented in $\mathrm{N}_{2}$ free basis and/or dry basis. No $\mathrm{CO}$ and $\mathrm{CO}_{2}$ concentrations were ever 
detected at the $\mathrm{AR}$ outlet in any test. Thus, no losses in $\mathrm{CO}_{2}$ capture were produced by carbon transfer to the $\mathrm{AR}$, with $100 \% \mathrm{CO}_{2}$ capture achieved in the process.

\subsubsection{Effect of fuel composition}

Fig. 4 shows the effect of $\phi$ on the combustion efficiency using the haematite mineral as oxygen carrier, using PSA off-gas, methane and syngas as fuel gases. Full conversion of the fuel was almost reached when syngas was fed in the fuel reactor, whatever the ratio $\mathrm{CO} / \mathrm{H}_{2}$ used due to the high reactivity of the haematite mineral with these gases. Lower conversion of the fuel was observed with methane containing fuels, i.e. PSA off-gas and $\mathrm{CH}_{4}$, because the lower reactivity of the haematite mineral with $\mathrm{CH}_{4}$, compared to $\mathrm{CO}$ and $\mathrm{H}_{2}$, as it was determined in TGA. In these cases, therefore, the higher $\mathrm{CH}_{4}$ content in the fuel, the lower combustion efficiency. The minor effect of increasing the oxygen carrier to fuel ratio on the $\mathrm{CH}_{4}$ conversion was due to the opposite effects of varying the fuel concentration and the solids inventory at the same time. It must be pointed out that experiments shown in Figure 4 were carried out at different fuel gas flow, increasing the fuel concentration but maintaining the solids inventory in the FR approximately constant. Therefore, as $\phi$ ratio increases, the fuel flow decreases, and the solids inventory in the FR per MW of fuel gas, $\mathrm{m}_{\mathrm{FR}}{ }^{*}$, increases, see Table 3. Nevertheless, the increase in $\phi$ and $\mathrm{m}_{\mathrm{FR}} *$ should produce an increase in the combustion efficiency. But otherwise, a decrease on the methane concentration produces a decrease on the reaction rate and therefore on the combustion efficiency (at constant $\mathrm{m}_{\mathrm{FR}}{ }^{*}$ ). From results shown in Figure 4, it can be concluded that the positive effect of increasing the solids inventory and oxygen carrier to fuel ratio on the combustion efficiency is almost compensate by the negative effect of the decrease of fuel concentration. 
The low conversion of methane was the main responsible of the low combustion efficiencies obtained as can be seen in Fig. 5, where the effect of the oxygen carrier-tofuel ratio on the gas product concentration measured at the outlet of the fuel reactor in dry and $\mathrm{N}_{2}$ free basis when PSA off-gas, $\mathrm{CH}_{4}$ or syngas was used as fuel gas. In all cases the amount of unconverted $\mathrm{H}_{2}$ and $\mathrm{CO}$ are very low. Using methane containing gases the main unconverted gas is $\mathrm{CH}_{4}$.

Different alternatives to increase the reactivity of the haematite mineral with $\mathrm{CH}_{4}$ were postulated, as increasing the fuel reactor temperature, or the addition of small amounts of highly reactive materials like a Ni-based $\mathrm{OC}$, who catalyzes the $\mathrm{CH}_{4}$ reforming to $\mathrm{CO}$ and $\mathrm{H}_{2}$ (Johansson et al., 2006b; Ryden et al., 2010a; Ryden et al., 2009; Ryden et al., $2010 \mathrm{~b}$ ), high reactive gases with the haematite mineral.

\subsubsection{Effect of fuel reactor temperature}

Fig. 6 shows the effect of $\phi$ on the combustion efficiency using the haematite mineral as an oxygen carrier, working with $\mathrm{CH}_{4}$ as fuel gas at 830,880 and $930^{\circ} \mathrm{C}$. The effect of the fuel reactor temperature on the combustion efficiency was found to be considerable, as was expected from the TGA reactivity analysis of the OC. However, full combustion of the fuel was not yet reached, even though the reactor was working at $930^{\circ} \mathrm{C}$. FR temperatures higher than $950^{\circ} \mathrm{C}$ are not possible in the process since $\mathrm{AR}$ temperatures higher than $1000^{\circ} \mathrm{C}$ are not feasible. From results shown in Fig. 6, it can be deduced that combustion efficiency would be also low at such high temperatures.

\subsubsection{Effect of the Ni addition.}


Several studies were performed with the addition of certain amount of nickel oxide using different experimental configurations as fixed bed (Ryden et al., 2008), batch fluidized bed reactor (Johansson et al., 2006b; Ryden et al., 2010a; Ryden et al., 2009), $300 \mathrm{~W}_{\text {th }}$ circulating fluidized bed reactor (Ryden et al., 2010b) and $500 \mathrm{~W}_{\text {th }}$ unit (Pans et al., 2013). Johansson et al. (Johansson et al. 2006b) found that a bed of iron oxides with only 3 wt.\% of a Ni-based material produced more than two times the $\mathrm{CO}_{2}$ amount in comparison to the sum of the materials tested separately when a mixture of $50 \% \mathrm{CH}_{4}$ and $50 \% \mathrm{H}_{2} \mathrm{O}$ was fed to a fluidized bed. These researchers showed that the mixedoxide system produced a synergy effect due to the catalytic action of the metallic Ni. Very similar findings were also observed by Ryden et al. (Ryden et al., 2010a) mixing NiO60- $\mathrm{MgAl}_{2} \mathrm{O}_{4}$ either in a bed of $\mathrm{Fe}_{2} \mathrm{O}_{3} 60-\mathrm{MgZrO}_{2}$, in a bed of ilmenite (Ryden et al., $2010 \mathrm{~b}$ ) or in a bed of waste products from the steel industry (Ryden et al., 2009). NiO contents ranged from 0.2 to $3 \mathrm{wt} . \%$. They obtained $90 \%$ of combustion efficiency in the $300 \mathrm{~W}_{\text {th }}$ CLC unit burning natural gas when a $1 \mathrm{wt} \%$ NiO-based particles were added to ilmenite in comparison with $76 \%$ for pure ilmenite. However, higher improvements were measured working in a batch fluidized bed adding 5 wt.\% NiObased particles. Also, Pans et al. (Pans et al., 2013) reported an increase in the combustion efficiency in a continuous $500 \mathrm{~W}_{\text {th }}$ CLC prototype using methane as fuel. It was found that the addition of $2 \mathrm{wt} \%$ of $\mathrm{NiO}$ to an impregnated Fe-based oxygen carrier had a measurable positive effect only when the fuel reactor temperature was lower than $850^{\circ} \mathrm{C}$. Therefore, in order to increase combustion efficiency when using $\mathrm{CH}_{4}$ as fuel, a small amount of a Ni-based $\mathrm{OC}$ was added to the haematite mineral. This Ni-based OC had previously been confirmed as a highly efficient oxygen carrier for the chemical looping reforming process of methane (de Diego et al., 2009). The main 
physical and chemical properties of the Ni-based OC are shown in Table 1. The necessary amount of Ni-based OC was added to obtain a mixture with $5 \mathrm{wt} \% \mathrm{NiO}$.

Fig. 7 a) shows the effect of $\phi$ on combustion efficiency when the physical mixture of mineral+Ni-based $\mathrm{OC}$ was used at $930^{\circ} \mathrm{C}$. No substantial improvement in combustion efficiency was measured, as can be observed when comparing these results to the ones obtained with the mineral at the same temperature. The $\mathrm{CH}_{4}$ concentration at the FR outlet was similar to the one achieved with the unmixed mineral, confirming the absence of any catalytic reforming effect from the Ni-based OC, as can be observed in Fig. 7 b).

\subsubsection{Analysis of the absence of catalytic effect}

The results obtained disagree with previous ones regarding the beneficial effect of $\mathrm{Ni}$ addition (Johansson et al., 2006b; Pans et al., 2013; Ryden et al., 2010a; Ryden et al., 2009; Ryden et al., 2010b; Ryden et al., 2008). In order to perform a deep analysis of this lack of catalytic effect in the results found in the continuous CLC unit, several studies were carried out in the batch fluidized bed reactor.

Firstly, several reducing cycles were carried out with a mixture of mineral and Ni-based OC with different reducing times in order to determine the gas product distribution.

Fig. 8.1 shows the outlet product gas distributions for different reduction periods of 330, 600 and 1200 seconds when working with the mixture mineral $+\mathrm{Ni}$-based OC, at $950^{\circ} \mathrm{C}$. As can be observed $5 \mathrm{vol}, \%$ unconverted $\mathrm{CH}_{4}$ leaves the reactor from the beginning. After 250 seconds, approximately, $\mathrm{CO}$ and $\mathrm{H}_{2}$ concentrations begins to increase and $\mathrm{CH}_{4}, \mathrm{CO}_{2}$ and $\mathrm{H}_{2} \mathrm{O}$ concentrations begins to decrease. At 1200 seconds all the $\mathrm{CH}_{4}$ is converted into a mixture of $\mathrm{CO}_{2}, \mathrm{CO}, \mathrm{H}_{2}$ and $\mathrm{H}_{2} \mathrm{O}$. OC samples were taken 
after each cycle i.e. at 330, 600 and 1200 seconds of reducing time, in order to identify the crystalline chemical species present in each sample by XRD patterns. Fig. 8.2 shows the XRD diffractograms. At 330 seconds, XRD patterns revealed the presence of the $\mathrm{Fe}_{3} \mathrm{O}_{4}$ and $\mathrm{NiO}$ forms. No metallic Ni was detected. At 600 seconds, metallic Ni appears, together with $\mathrm{Fe}_{3} \mathrm{O}_{4}$ and $\mathrm{FeO}$ forms. Finally, at 1200 seconds, only $\mathrm{Ni}^{0}$ and FeO were detected in the sample.

This data reveals that the metallic $\mathrm{Ni}^{0}$ appears together with the $\mathrm{FeO}$ form. When $\mathrm{Fe}_{2} \mathrm{O}_{3}$ was reduced to $\mathrm{Fe}_{3} \mathrm{O}_{4}$, the $\mathrm{OC}$ was able to convert the $\mathrm{CH}_{4}$ into $\mathrm{CO}_{2}$ and $\mathrm{H}_{2} \mathrm{O}$, and no $\mathrm{H}_{2}$ was generated to reduce $\mathrm{NiO}$ to $\mathrm{Ni}^{0}$. When $\mathrm{Fe}_{3} \mathrm{O}_{4}$ started to become reduced to $\mathrm{FeO}$, the oxygen carrier thermodynamically was not able to fully convert the $\mathrm{CH}_{4}$ into $\mathrm{CO}_{2}$ and $\mathrm{H}_{2} \mathrm{O}$, and partial combustion of the fuel took place, generating $\mathrm{CO}$ and $\mathrm{H}_{2}$. The resulting $\mathrm{H}_{2}$ reduced the $\mathrm{NiO}$ to $\mathrm{Ni}^{0}$, and the metallic $\mathrm{Ni}$ was able to catalyse the $\mathrm{CH}_{4}$ decomposition. So, only when all the $\mathrm{Fe}_{2} \mathrm{O}_{3}$ was completely reduced to $\mathrm{Fe}_{3} \mathrm{O}_{4}$ and the $\mathrm{Fe}_{3} \mathrm{O}_{4}$ form started to become reduced to $\mathrm{FeO}$, could the $\mathrm{NiO}$ be reduced to $\mathrm{Ni}^{0}$.

The product distribution obtained in the batch experiments was confirmed by thermodynamic simulation with the HSC Chemistry 6.1 program (HSC Chemistry 6.1®). The simulation was carried out at $950^{\circ} \mathrm{C}$ and 1 bar. Fig. 9 shows the amount of all the different species as a function of the $\mathrm{CH}_{4}$ feed. As can be seen, when $\mathrm{Fe}_{2} \mathrm{O}_{3}$ and $\mathrm{Fe}_{3} \mathrm{O}_{4}$ coexist, the $\mathrm{CH}_{4}$ is converted to $\mathrm{CO}_{2}$ and $\mathrm{H}_{2} \mathrm{O}$, and $\mathrm{NiO}$ remains in its oxidized form. When the $\mathrm{Fe}_{3} \mathrm{O}_{4}$ concentration begins to decrease and $\mathrm{FeO}$ concentration increases, $\mathrm{H}_{2}$ and $\mathrm{CO}$ concentrations begin to increase, as a consequence of the partial combustion of $\mathrm{CH}_{4}$, and $\mathrm{NiO}$ is reduced to $\mathrm{Ni}^{0}$ by the $\mathrm{H}_{2}$ produced.

Moreover, the $\mathrm{Ni}^{0}$ may have been oxidized by the $\mathrm{H}_{2} \mathrm{O}$ formed in the combustion reaction, preventing the catalytic reformer effect of the metallic Ni. In order check if this reaction would occur in the FR, a test was carried out in the batch fluidized bed 
reactor with a mixture of haematite mineral and the Ni-based OC. The $\mathrm{NiO}$ present in the Ni-based OC had previously been reduced to $\mathrm{Ni}^{0}$ in the batch fluidized bed reactor with $\mathrm{H}_{2}$. The reduction period was $1 \mathrm{~h}$, in order to reduce the NiO completely. After the experiment, a sample was analysed by XRD patterns, confirming that the $\mathrm{NiO}$ was completely reduced to $\mathrm{Ni}^{0}$.

The reduced Ni-based OC was mixed with the haematite mineral OC, obtaining a mixture with $2 \mathrm{wt} . \% \mathrm{NiO}$. The test was carried out at $950^{\circ} \mathrm{C}$ with $15 \mathrm{vol} . \% \mathrm{CH}_{4}$ and 20 vol. $\% \mathrm{H}_{2}$. The reduction time was 270 seconds, in order to reduce the $\mathrm{Fe}_{2} \mathrm{O}_{3}$ to $\mathrm{Fe}_{3} \mathrm{O}_{4}$, as happens inside the FR. After reaction, XRD patterns of the sample showed the presence of the oxidized $\mathrm{NiO}$ together with $\mathrm{Fe}_{3} \mathrm{O}_{4}$, confirming that $\mathrm{H}_{2} \mathrm{O}$ oxidized the reduced $\mathrm{Ni}^{0}$.

As commented previously, the results achieved with Ni addition disagree with the ones found so far in the literature. The reasons for this could be the impossibility of reducing the $\mathrm{NiO}$ under the operation conditions used. The presence of $\mathrm{Fe}_{3} \mathrm{O}_{4}$ and $\mathrm{H}_{2} \mathrm{O}$ in the FR prevents the reduction of $\mathrm{NiO}$ to $\mathrm{Ni}^{0}$. A high $\mathrm{H}_{2}$ concentration is necessary to reduce NiO. If $\mathrm{Ni}^{0}$ is formed, it can catalyse the $\mathrm{CH}_{4}$, reforming and improving combustion efficiency. Low $\mathrm{H}_{2}$ concentrations were measured in the continuous unit (Fig. 7 b). Therefore, $\mathrm{NiO}$ reduction did not occur in the FR and an absence of the catalytic reforming effect was found.

\subsubsection{Oxygen carrier behaviour}

It is important that the OC can survive for a long period of time in a CLC system. A total run lasting $56 \mathrm{~h}$ in hot conditions was carried out in continuous operation, of which $50 \mathrm{~h}$ corresponded to combustion conditions. A $1.7-\mathrm{kg}$ batch of particles was used 
without replacement or the addition of new material. During operation, different solid samples were taken from the cyclones and filters in order to study any variations in their physical and chemical properties with time. It must be pointed out that the oxygen carrier particles never presented any problems of agglomeration or defluidization throughout the entire operation time.

Attrition and fragmentation of particles was also analysed during the process. Particles elutriated from the fluidized bed reactors during operation were recovered in the cyclones and filters and weighted to determine the attrition rate. Those particles below $40 \mu \mathrm{m}$ in size were assumed as attrition. Fig. 10 shows the evolution over time of the attrition rate of the oxygen carrier during the whole operation in the continuous unit. The attrition rate was high during the first hours as a consequence of the rounding effects on the irregularities of the particles and because of the fines stuck to the particles during their preparation. However, the attrition rate after $20 \mathrm{~h}$ of operation stabilized at approximately $0.05 \mathrm{wt} \% / \mathrm{h}$ which remained roughly constant up to the 50 hours of operation. This attrition rate corresponded to a particle lifetime of $2000 \mathrm{~h}$. An oxygen carrier with high attrition can be a problem during operation in CLC. Nevertheless, the attrition rate measured with the iron ore in the CLC system was low considering its low cost.

The evolution of the textural and structural properties of the oxygen carrier was studied by means of different techniques. Table 2 shows the main properties of this batch of used oxygen carrier particles and were compared to those of fresh particles. A slight decrease in the mechanical strength of the particles, from $4.6 \mathrm{~N}$ to $3.0 \mathrm{~N}$, was observed after operation at high temperatures.

The real density of the used particles presented a very slight decrease. Carrier porosity decreased slightly and the BET surface area remained at low values after operation. The 
$\mathrm{Fe}_{2} \mathrm{O}_{3}$ content of the used particles was also determined by complete reduction of the sample with hydrogen by TGA. The iron content in the oxygen carrier remained constant, maintaining the oxygen transport capacity of the material.

The powder XRD patterns of the used carrier revealed the presence of the same compounds as those in the calcined particles, indicating the stability of the main inert oxides present in the material $\left(\mathrm{Al}_{2} \mathrm{O}_{3}\right.$ and $\left.\mathrm{SiO}_{2}\right)$. No other iron phases other than haematite and magnetite were found in the different samples analysed during operation coming from the fuel and air reactor. Haematite was found in samples extracted from the air reactor, whereas magnetite also appeared in the samples taken from the fuel reactor. This fact indicates that full oxidation of the oxygen carrier was achieved in the air reactor.

Samples were also analyzed by SEM-EDX techniques in order to determine the possible structural changes undergone by the particles. According to the SEM pictures, morphological changes were not observed in the particles. However, a change in the $\mathrm{Ca}$ and $\mathrm{Mg}$ distribution throughout the particle was detected. In the calcined samples, the surface seems to be $\mathrm{Ca}$ - and $\mathrm{Mg}$-enriched. After operation in the continuous unit, it can be observed that the external surface of the iron ore particles were not more $\mathrm{Ca}$ and $\mathrm{Mg}$ enriched.

\section{Conclusions}

A natural iron ore coming from a haematite mine and composed mainly of $\mathrm{Fe}_{2} \mathrm{O}_{3}$ was tested as an oxygen carrier in a continuous CLC facility burning different fuel gases $\left(\mathrm{CH}_{4}, \mathrm{CO}, \mathrm{H}_{2}\right.$ and PSA off-gas). 
The oxygen carrier was first characterized by TGA to determine the $\mathrm{CH}_{4}, \mathrm{CO}$ and $\mathrm{H}_{2}$ reactivity of the oxygen carrier. The oxygen carrier exhibited very fast reduction and oxidation rates with $\mathrm{H}_{2}$ and $\mathrm{CO}$ and low reactivity with $\mathrm{CH}_{4}$.

Continuous operation in a $500 \mathrm{~W}_{\text {th }}$ CLC facility was performed in a run lasting $56 \mathrm{~h}$. The effect of the fuel reactor temperature on the combustion efficiency was analysed. The oxygen carrier showed enough reactivity to fully convert the simulated syngas at $880^{\circ} \mathrm{C}$, regardless of the $\mathrm{CO} / \mathrm{H}_{2}$ ratio used. However, lower conversion of the fuel was observed with methane-containing fuels because of the lower reactivity of the oxygen carrier with this gas.

A physical addition of a Ni-based OC was carried out in order to increase the combustion efficiency of $\mathrm{CH}_{4}$. No improvement in the combustion efficiency was measured when working with $5 \mathrm{wt} . \% \mathrm{NiO}$ at $930^{\circ} \mathrm{C}$. The absence of the catalytic effect of $\mathrm{Ni}$ in the tests carried out in the continuous unit was explained by the presence of $\mathrm{Fe}_{3} \mathrm{O}_{4}$ as the reduced iron compound.

The oxygen carrier did not present problems of agglomeration or defluidization, and the measured attrition rate was low. Thus, a low cost iron ore-based material, has been successfully found for CLC operation with syngas.

\section{Acknowledgments}

P. Gayán thanks CSIC for the financial support given to the project 201180E102. M.A. Pans thanks MICINN for the FPI fellowship. The authors also thank PROMINDSA for providing the iron ore used in this work.

\section{References}


Abad, A., Mattisson, T., Lyngfelt, A., Ryden, M., 2006. Chemical-looping combustion in a $300 \mathrm{~W}$ continuously operating reactor system using a manganese-based oxygen carrier. Fuel 85, 1174-1185.

Abad, A., Adanez, J., Garcia-Labiano, F., de Diego, L.F., Gayan, P., Celaya, J., 2007a. Mapping of the range of operational conditions for $\mathrm{Cu}-, \mathrm{Fe}-$, and Ni-based oxygen carriers in chemical-looping combustion. Chem. Eng. Sci. 62, 533-549.

Abad, A., Garcia-Labiano, F., de Diego, L.F., Gayan, P., Adanez, J., 2007b. Reduction kinetics of $\mathrm{Cu}-, \mathrm{Ni}-$, and $\mathrm{Fe}-$ based oxygen carriers using syngas $(\mathrm{CO}+\mathrm{H} 2)$ for chemical-looping combustion. Energy Fuels 21, 1843-1853.

Abad, A., Mattisson, T., Lyngfelt, A., Johansson, M., 2007c. The use of iron oxide as oxygen carrier in a chemical-looping reactor. Fuel 86, 1021-1035.

Adanez, J., Abad, A., Garcia-Labiano, F., Gayan, P., de Diego, L.F., 2012. Progress in Chemical-Looping Combustion and Reforming technologies. Progr. Energy Combust. Sci. 38, 215-282.

Adanez, J., de Diego, L.F., Garcia-Labiano, F., Gayan, P., Abad, A., Palacios, J.M., 2004. Selection of oxygen carriers for chemical-looping combustion. Energy Fuels 18, 371-377.

Adanez, J., Dueso, C., de Diego, L.F., Garcia-Labiano, F., Gayan, P., Abad, A., 2009. Methane Combustion in a $500 \mathrm{~W}$-th Chemical-Looping Combustion System Using an Impregnated Ni-Based Oxygen Carrier. Energy Fuels 23, 130-142.

Adanez, J., Cuadrat, A., Abad, A., Gayan, P., de Diego, L.F., Garcia-Labiano, F., 2010. Ilmenite Activation during Consecutive Redox Cycles in Chemical-Looping Combustion. Energy Fuels 24, 1402-1413. 
Azis, M.M., Jerndal, E., Leion, H., Mattisson, T., Lyngfelt, A., 2010. On the evaluation of synthetic and natural ilmenite using syngas as fuel in chemical-looping combustion (CLC). Chem. Eng. Res. Des. 88, 1505-1514.

Cuadrat, A., Abad, A., Adánez, J., de Diego, L.F., García-Labiano, F., Gayán, P., 2009. Behaviour of Ilmenite as Oxygen Carrier in Chemical-Looping Combustion, International Conference on Clean Coal Technologies, Dresden, Germany.

Cho, P., Mattisson, T., Lyngfelt, A., 2006. Defluidization conditions for a fluidized bed of iron oxide-, nickel oxide-, and manganese oxide-containing oxygen carriers for chemical-looping combustion. Ind. Eng. Chem. Res. 45, 968-977.

de Diego, L.F., Ortiz, M., Garcia-Labiano, F., Adanez, J., Abad, A., Gayan, P., 2009. Hydrogen production by chemical-looping reforming in a circulating fluidized bed reactor using Ni-based oxygen carriers. J. Power Sources 192, 27-34.

Dueso, C., Garcia-Labiano, F., Adanez, J., de Diego, L.F., Gayan, P., Abad, A., 2009. Syngas combustion in a chemical-looping combustion system using an impregnated Ni-based oxygen carrier. Fuel 88, 2357-2364.

Final report. CACHET project (FP VI-019972).

Gayan, P., Dueso, C., Abad, A., Adanez, J., de Diego, L.F., Garcia-Labiano, F., 2009. $\mathrm{NiO} / \mathrm{Al} 2 \mathrm{O} 3$ oxygen carriers for chemical-looping combustion prepared by impregnation and deposition-precipitation methods. Fuel 88, 1016-1023.

Gayan, P., Pans, M.A., Ortiz, M., Abad, A., de Diego, L.F., Garcia-Labiano, F., Adanez, J., 2012. Testing of a highly reactive impregnated Fe2O3/Al2O3 oxygen carrier for a SR-CLC system in a continuous CLC unit. Fuel Process. Technol. 96, 37-47. 
HSC Chemistry 6.1®, Chemical Reaction and Equilibrium Software with Thermochemical Database and Simulation Module. Oututec Research Oy, Pori, Finland.

IPPC, 2005. Carbon Dioxide Capture and Storage Cambridge University Press, Cambridge, England.

Ishida, M., Yamamoto, M., Ohba, T., 2002. Experimental results of chemical-looping combustion with $\mathrm{NiO} / \mathrm{NiAl} 2 \mathrm{O} 4$ particle circulation at 1200 degrees C. Energy Conv. Manag. 43, 1469-1478.

Johansson, E., Mattisson, T., Lyngfelt, A., Thunman, H., 2006a. Combustion of syngas and natural gas in a $300 \mathrm{~W}$ chemical-looping combustor. Chem. Eng. Res. Des. $84,819-827$.

Johansson, M., Mattisson, T., Lyngfelt, A., 2006b. Creating a synergy effect by using mixed oxides of iron- and nickel oxides in the combustion of methane in a chemical-looping combustion reactor. Energy Fuels 20, 2399-2407.

Leion, H., Lyngfelt, A., Johansson, M., Jerndal, E., Mattisson, T., 2008. The use of ilmenite as an oxygen carrier in chemical-looping combustion. Chem. Eng. Res. Des. 86, 1017-1026.

Levenspiel, O., 1981. Chemical Reaction Engineering, New York.

Liu, F., Zhang, Y., Chen, L., Qian, D., Neathery, J.K., Kozo, S., Liu, K., 2013. Investigation of a Canadian Ilmenite as an Oxygen Carrier for Chemical Looping Combustion. Energy Fuels 27, 5987-5995.

Mattisson, T., Johansson, M., Lyngfelt, A., 2006. The use of $\mathrm{NiO}$ as an oxygen carrier in chemical-looping combustion. Fuel 85, 736-747. 
Mendiara, T., Abad, A., de Diego, L.F., Garcia-Labiano, F., Gayan, P., Adanez, J., 2012a. Use of an Fe-Based Residue from Alumina Production as an Oxygen Carrier in Chemical-Looping Combustion. Energy Fuels 26, 1420-1431.

Mendiara, T., Perez, R., Abad, A., de Diego, L.F., Garcia-Labiano, F., Gayan, P., Adanez, J., 2012b. Low-Cost Fe-Based Oxygen Carrier Materials for the iGCLC Process with Coal. 1. Ind. Eng. Chem. Res. 51, 16216-16229.

Mendiara, T., de Diego, L.F., Garcia-Labiano, F., Gayan, P., Abad, A., Adanez, J., 2014. On the use of a highly reactive iron ore in Chemical Looping Combustion of different coals. Fuel 126, 239-249.

Moghtaderi, B., Song, H., 2010. Reduction Properties of Physically Mixed Metallic Oxide Oxygen Carriers in Chemical Looping Combustion. Energy Fuels 24, $5359-5368$.

Ortiz, M., de Diego, L.F., Gayán, P., Pans, M.A., García-Labiano, F., Abad, A., Adánez, J., 2010. Hydrogen production by steam reforming coupled with $\mathrm{CO}_{2}$ capture by chemical-looping combustion using mixed Fe-Ni oxygen carriers, $1^{\text {st }}$ Int. Conf. on Chemical-Looping, Lyon, France.

Ortiz, M., Gayan, P., de Diego, L.F., Garcia-Labiano, F., Abad, A., Pans, M.A., Adanez, J., 2011. Hydrogen production with CO2 capture by coupling steam reforming of methane and chemical-looping combustion: Use of an iron-based waste product as oxygen carrier burning a PSA tail gas. J. Power Sources 196, $4370-4381$.

Pans, M.A., Gayán, P., Abad, A., García-Labiano, F., De Diego, L.F., Adánez, J., 2013. Use of chemically and physically mixed iron and nickel oxides as oxygen carriers for gas combustion in a CLC process. Fuel Process. Technol. 115, 152163. 
Proll, T., Mayer, K., Bolhar-Nordenkampf, J., Kolbitsch, P., Mattisson, T., Lyngfelt, A., Hofbauer, H., 2009. Natural minerals as oxygen carriers for chemical looping combustion in a dual circulating fluidized bed system, in: Gale, J., Herzog, H., Braitsch, J. (Eds.), Greenhouse Gas Control Technologies 9. Elsevier Science Bv, Amsterdam, pp. 27-34.

Ryden, M., Lyngfelt, A., Mattisson, T., Chen, D., Holmen, A., Bjorgum, E., 2008. Novel oxygen-carrier materials for chemical-looping combustion and chemical-looping reforming; LaxSr1-xFeyCo1-yO3-delta perovskites and mixed-metal oxides of $\mathrm{NiO}, \mathrm{Fe} 2 \mathrm{O} 3$ and $\mathrm{Mn} 3 \mathrm{O} 4$. International Journal of Greenhouse Gas Control 2, 21-36.

Ryden, M., Cleverstam, E., Lyngfelt, A., Mattisson, T., 2009. Waste products from the steel industry with $\mathrm{NiO}$ as additive as oxygen carrier for chemical-looping combustion. International Journal of Greenhouse Gas Control 3, 693-703.

Ryden, M., Cleverstam, E., Johansson, M., Lyngfelt, A., Mattisson, T., 2010a. Fe2O3 on Ce-, $\mathrm{Ca}-$, or $\mathrm{Mg}$-Stabilized $\mathrm{ZrO} 2$ as Oxygen Carrier for Chemical-Looping Combustion Using NiO as Additive. AIChE J. 56, 2211-2220.

Ryden, M., Johansson, M., Cleverstam, E., Lyngfelt, A., Mattisson, T., 2010b. Ilmenite with addition of $\mathrm{NiO}$ as oxygen carrier for chemical-looping combustion. Fuel 89, 3523-3533.

Song, Q.L., Xiao, R., Deng, Z.Y., Zhang, H.Y., Shen, L.H., Xiao, J., Zhang, M.Y., 2008. Chemical-looping combustion of methane with CaSO4 oxygen carrier in a fixed bed reactor. Energy Conv. Manag. 49, 3178-3187. 


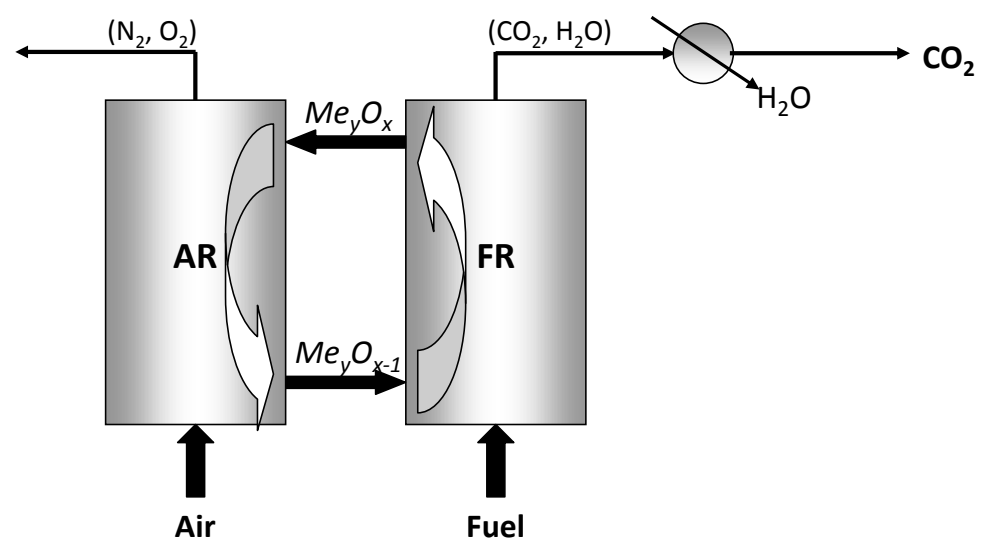

Fig. 1. Schematic diagram of a CLC system. 


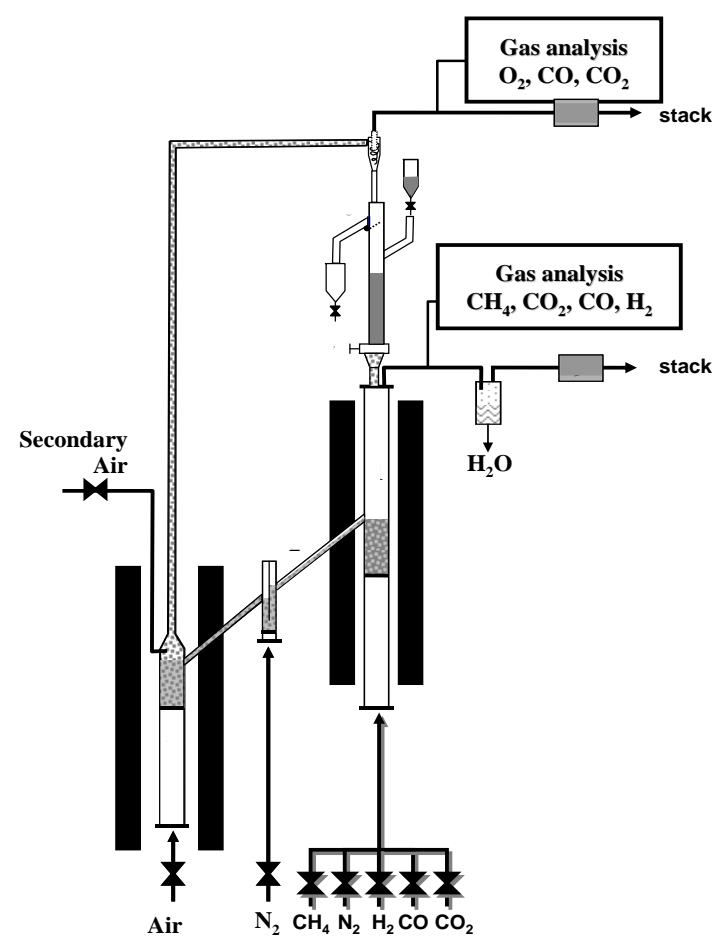

Fig. 2. Schematic diagram of the ICB-CSIC-g1 facility. 
a)

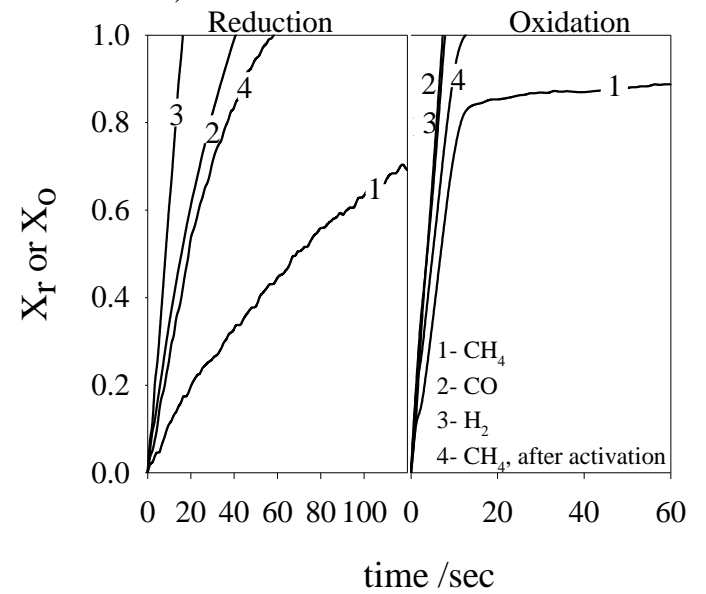

b)

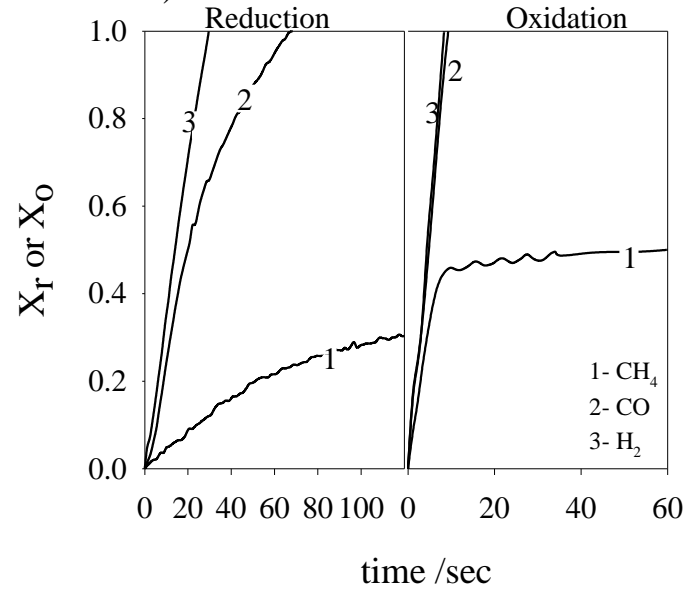

Fig. 3. Conversion vs. time curves using the haematite mineral. Oxidation: air. a) $\mathrm{T}=950^{\circ} \mathrm{C}$; b) $\mathrm{T}=$ $830^{\circ} \mathrm{C}$ 


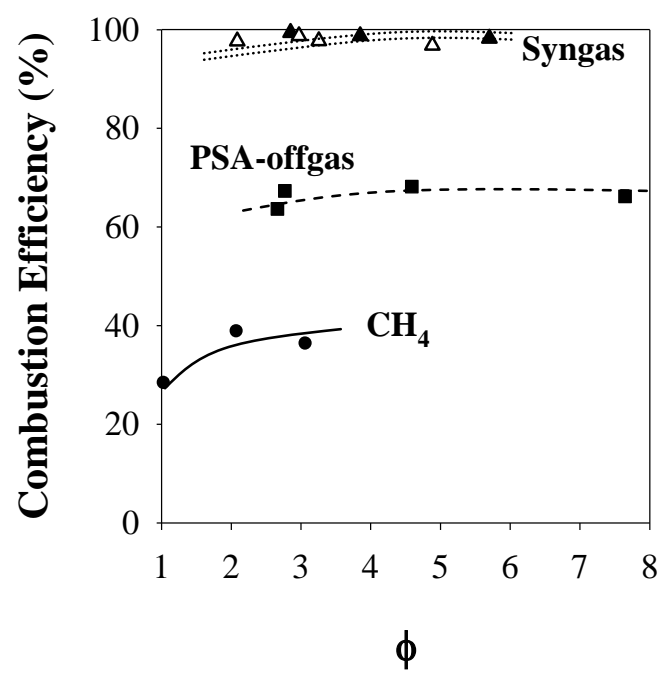

Fig. 4. Effect of oxygen carrier to fuel ratio on the combustion efficiency using different fuels at $880^{\circ} \mathrm{C}$ with PSA off-gas, $\mathrm{CH}_{4}$ and syngas. With syngas: $\mathrm{CO} / \mathrm{H}_{2}=1$ (filled dots); $\mathrm{CO} / \mathrm{H}_{2}=3$ (empty dots). 


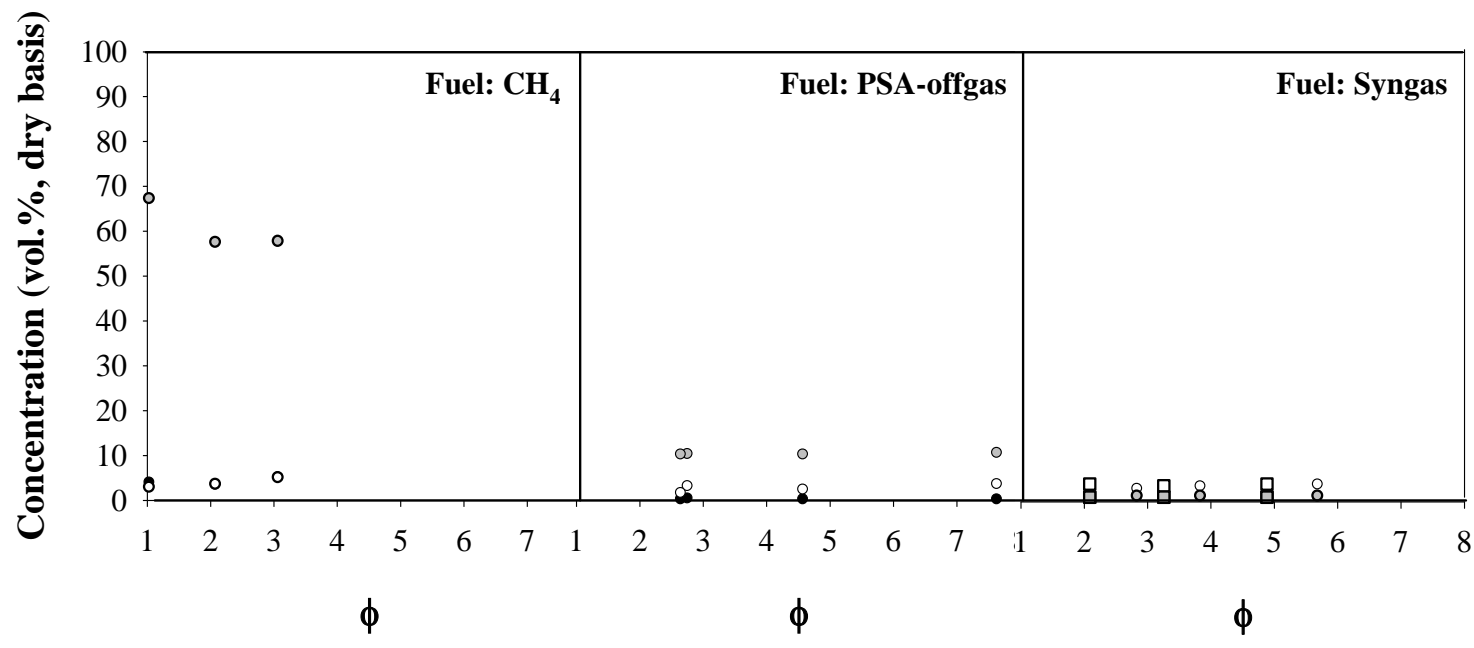

Fig. 5. Effect of oxygen carrier to fuel ratio on the composition of outlet gases using different fuels $\left(\mathrm{CH}_{4}\right.$, PSA off-gas and syngas $\left.\mathrm{CO} / \mathrm{H}_{2}=1\right)$ at $880^{\circ} \mathrm{C}$ with the haematite mineral: $(\bullet) \mathrm{H}_{2},(\mathrm{O}) \mathrm{CH}_{4}$ and (O) CO. Using syngas with $\mathrm{CO} / \mathrm{H}_{2}=3:(\mathbf{a}) \mathrm{H}_{2}$, , (口) $\mathrm{CH}_{4},(\square) \mathrm{CO}$. 


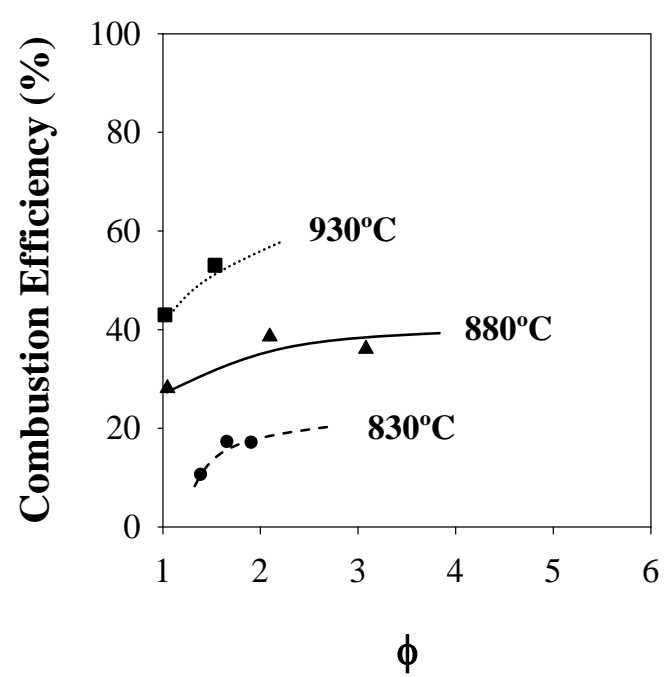

Fig. 6. Effect of oxygen carrier to fuel ratio on the combustion efficiency at different FR temperatures using $\mathrm{CH}_{4}$ as fuel. 

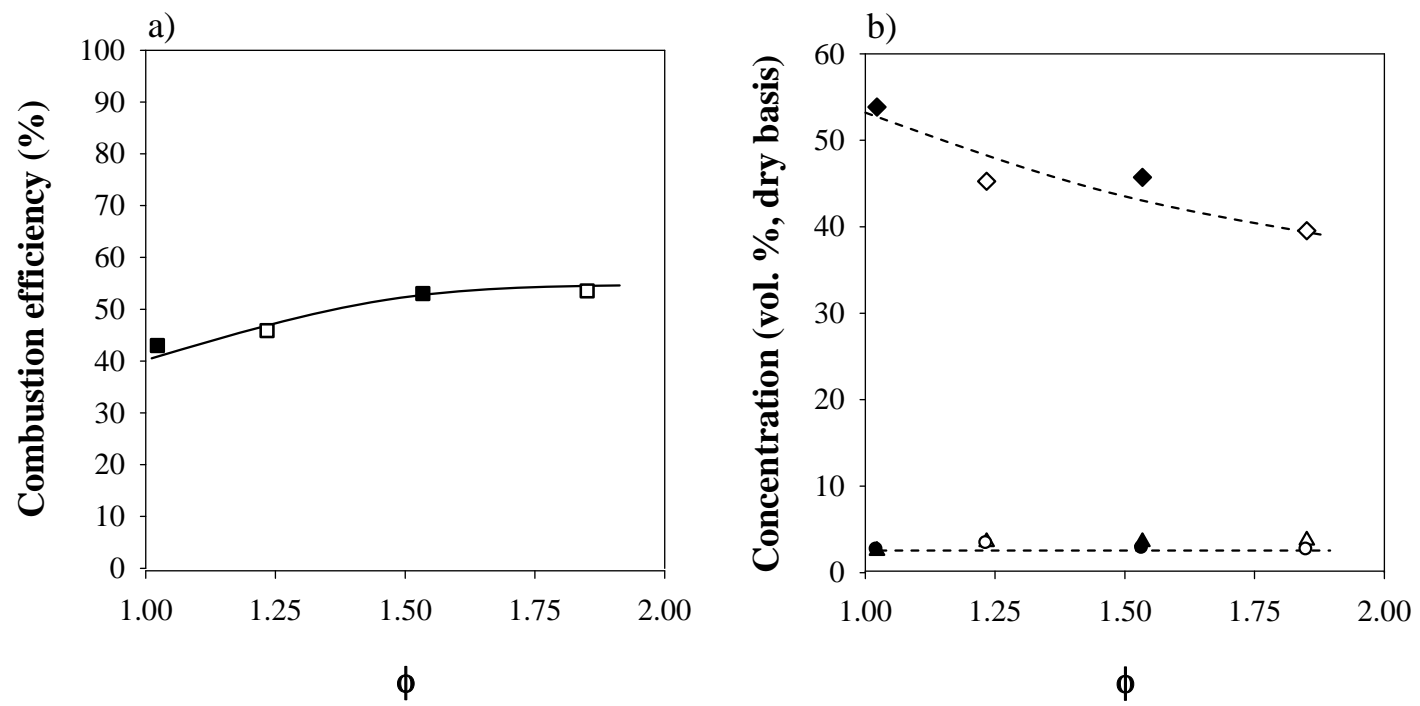

Fig. 7. a) Effect of oxygen carrier to fuel ratio on the combustion efficiency using $\mathrm{CH}_{4}$ as fuel. Haematite mineral; $(\square)$ Haematite mineral $+5 \% \mathrm{NiO} \cdot \mathrm{T}_{\mathrm{RR}}=930^{\circ} \mathrm{C}$.

b) Effect of oxygen carrier to fuel ratio on the composition of outlet gases using $\mathrm{CH}_{4}$ as fuel. ( $\mathbf{A}$ ) $\mathrm{CO}$, mineral; $(\triangle) \mathrm{CO}$, mineral $+5 \% \mathrm{NiO} ;(\bullet) \mathrm{H}_{2}$, mineral; $(\mathrm{O}) \mathrm{H}_{2}$, mineral $+5 \% \mathrm{NiO} ;(\bullet) \mathrm{CH}_{4}$, mineral; ( $\mathrm{CH}_{4}$, mineral $+5 \% \mathrm{NiO} \cdot \mathrm{T}_{\mathrm{RR}}=930^{\circ} \mathrm{C}$. 


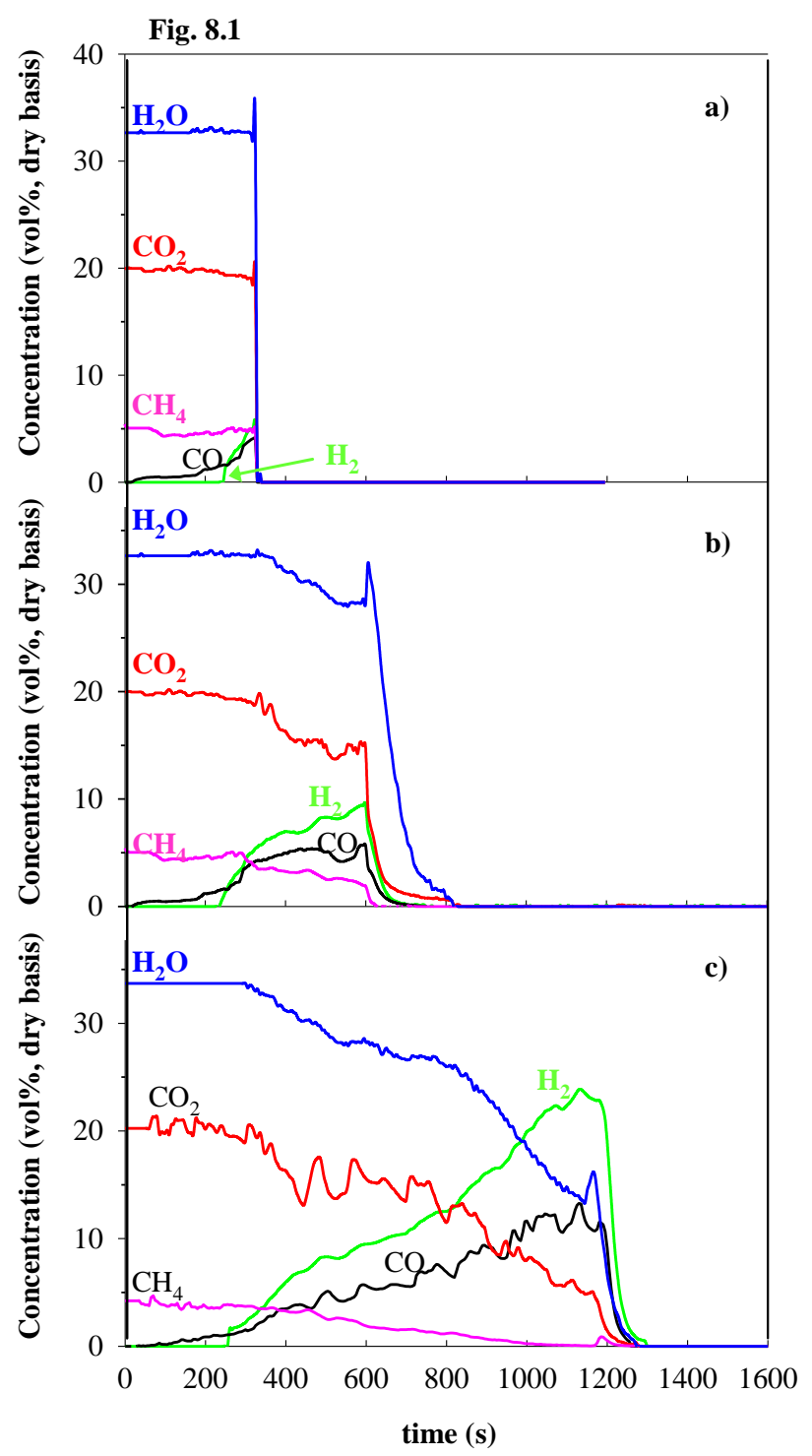

Fig. 8.2
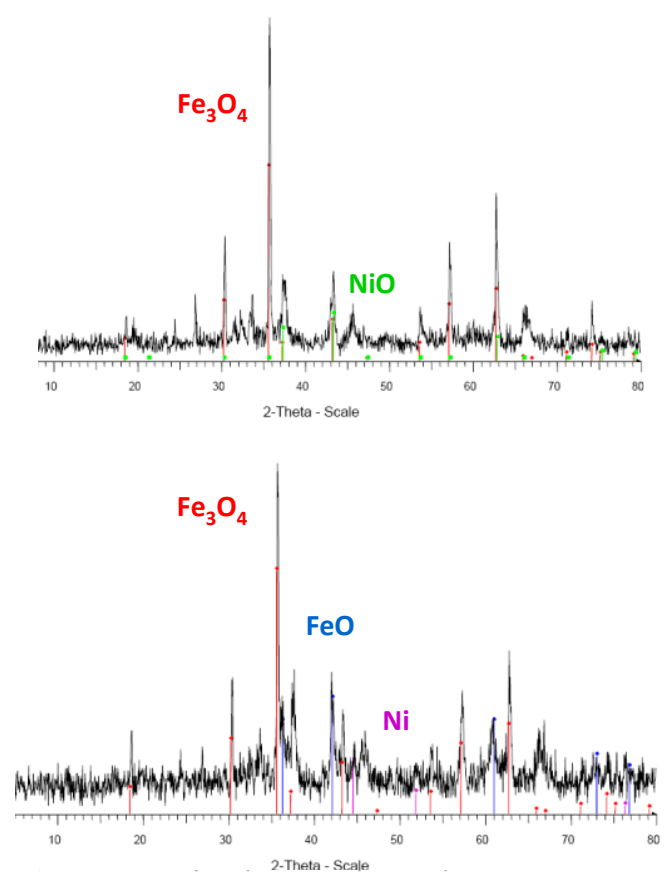

Fig. 8.1. Product gas distribution in dry basis during reduction using the mixture haematite mineral+Nibased OC. a) $t_{\text {red }}=330 \mathrm{~s}$; b) $t_{\text {red }}=600 \mathrm{~s}$; c) $t_{r e d}=1200 \mathrm{~s} . \mathrm{H}_{2} \mathrm{O}$ concentration as measured in an FTIR analyser. $\mathrm{T}=950^{\circ} \mathrm{C}$, Fuel $=25$ vol $\% \mathrm{CH}_{4}$ and 10 vol $\% \mathrm{H}_{2} \mathrm{O}$.

Fig. 8.2. XRD diffractograms of samples extracted of the batch fluidized bed reactor corresponding to cycles a), b) y c). 


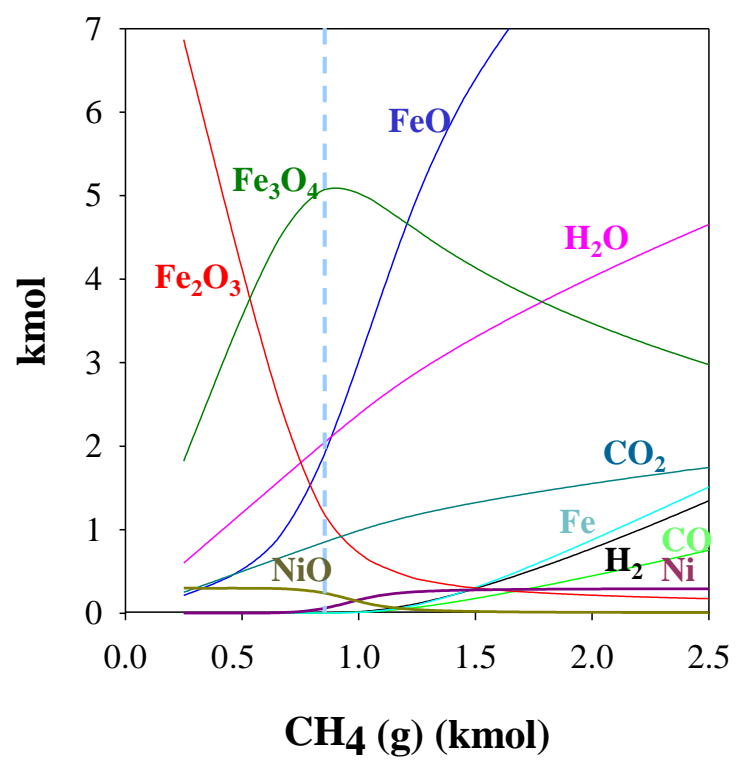

Fig. 9. Thermodynamic equilibrium as a function of the $\mathrm{CH}_{4}$ amount fed to the system. $\mathrm{T}=950^{\circ} \mathrm{C} . \mathrm{P}=1$ bar. 


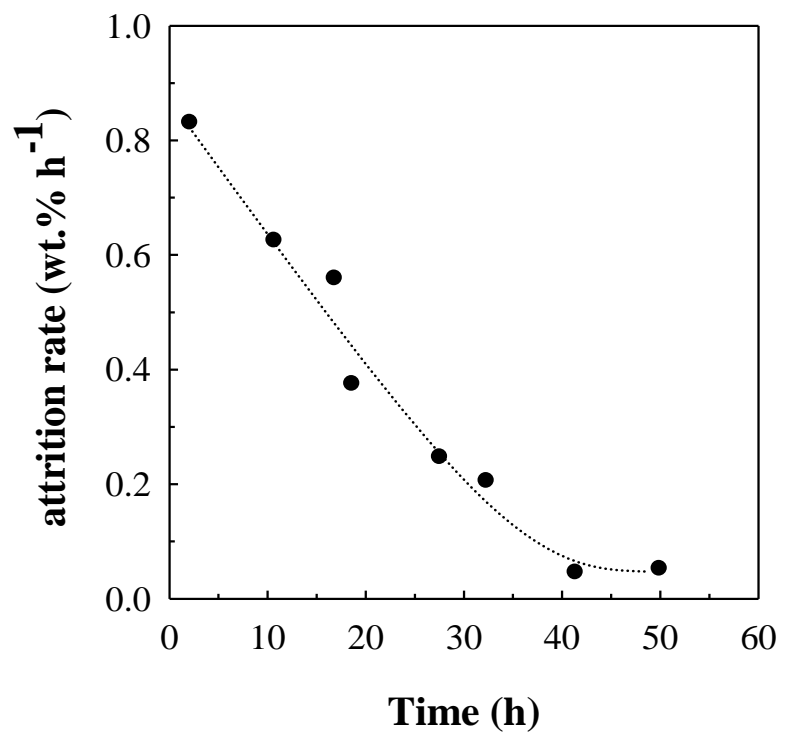

Fig. 10. Attrition rate versus time measured in the CLC unit. 


\section{Captions for tables}

Tabla 1. Mineral composition determined by ICP-AES.

Table 2. Main characteristics of the oxygen carrier.

Table 3. Operating conditions and main data for the experiments carried out in the ICB-CSIC-g1 facility using different fuels. 
Table 1. Mineral composition determined by ICP-AES.

\begin{tabular}{lc}
\hline Compound & Wt\% \\
\hline $\mathrm{Fe}_{2} \mathrm{O}_{3}$ & 78.8 \\
$\mathrm{Al}_{2} \mathrm{O}_{3}$ & 4.0 \\
$\mathrm{CaO}$ & 4.7 \\
$\mathrm{~K}_{2} \mathrm{O}$ & 1.1 \\
$\mathrm{MgO}$ & 3.0 \\
$\mathrm{Na}_{2} \mathrm{O}$ & 0.1 \\
$\mathrm{SiO}_{2}$ & 8.2 \\
$\mathrm{TiO}_{2}$ & 0.1 \\
\hline
\end{tabular}


Table 2. Main characteristics of the oxygen carrier.

Haematite mineral fresh after used

\begin{tabular}{|c|c|c|c|c|}
\hline & & fresh & after used $^{\mathrm{a}}$ & fresh \\
\hline $\mathrm{Fe}_{2} \mathrm{O}_{3}{ }^{\mathrm{b}}(\mathrm{wt} \%)$ & & 76.0 & 76.0 & \\
\hline $\mathrm{NiO}^{\mathrm{b}}(\mathrm{wt} \%)$ & & & & 18.0 \\
\hline Oxygen transport capacity ${ }^{\mathrm{c}}(\%)$ & & 2.54 & 2.54 & 3.90 \\
\hline Crushing strength $(\mathrm{N})$ & & 4.6 & 3.0 & 4.1 \\
\hline Real density $\left(\mathrm{g} / \mathrm{cm}^{3}\right)$ & & 4.5 & 4.3 & - \\
\hline Porosity (\%) & & 25.4 & 17.5 & 42.5 \\
\hline Specific surface area, BET $\left(\mathrm{m}^{2} / \mathrm{g}\right)$ & & 1.0 & 0.4 & 7.0 \\
\hline \multicolumn{5}{|c|}{ XRD } \\
\hline Fresh & & $\begin{array}{c}\mathrm{Fe}_{2} \mathrm{O}_{3}, \mathrm{SiO}_{2}, \\
\mathrm{CaO}, \mathrm{MgO}\end{array}$ & & $\begin{array}{c}\alpha-\mathrm{Al}_{2} \mathrm{O}_{3}, \mathrm{NiO} \\
\mathrm{NiAl}_{2} \mathrm{O}_{4}\end{array}$ \\
\hline \multirow[t]{2}{*}{ Used CLC } & Particles from AR & & $\mathrm{Fe}_{2} \mathrm{O}_{3}, \mathrm{SiO}_{2}$ & \\
\hline & Particles from FR & & $\begin{array}{c}\mathrm{Fe}_{2} \mathrm{O}_{3}, \mathrm{SiO}_{2} \\
\mathrm{Fe}_{3} \mathrm{O}_{4}\end{array}$ & \\
\hline
\end{tabular}

\footnotetext{
${ }^{\mathrm{a}} 56 \mathrm{~h}$ CLC unit

${ }^{\mathrm{b}}$ Determined by TGA

${ }^{\mathrm{c}} R_{O C}=\left(\mathrm{m}_{\mathrm{ox}}-\mathrm{m}_{\mathrm{red}}\right) / \mathrm{m}_{\mathrm{ox}}$
} 
Table 3. Operating conditions and main data for the experiments carried out in the ICB-CSIC-g1 facility using different fuels.

\begin{tabular}{|c|c|c|c|c|c|c|}
\hline Test & $\begin{array}{c}\text { Fuel gas }^{\text {a }} \\
(\text { vol\% } \%)\end{array}$ & $\mathbf{T}_{\mathbf{F R}}$ & $\mathbf{f}_{\mathrm{s}}(\mathrm{kg} / \mathrm{h})$ & $\phi$ & Power $\left(\mathbf{W}_{\text {th }}\right)$ & $\begin{array}{c}m_{F R}^{*} \\
\left(\mathrm{~kg} / \mathrm{MW}_{\mathrm{th}}\right)\end{array}$ \\
\hline \multicolumn{7}{|l|}{$\mathrm{CH}_{4}$} \\
\hline M-1 & 20.0 & 830 & 10.0 & 1.4 & 598 & 509 \\
\hline M-2 & 16.8 & 830 & 10.0 & 1.7 & 501 & 608 \\
\hline M-3 & 14.6 & 830 & 10.0 & 1.9 & 434 & 698 \\
\hline M-4 & 50.0 & 880 & 16.7 & 1.1 & 1493 & 204 \\
\hline M-5 & 25.0 & 880 & 16.7 & 2.1 & 747 & 408 \\
\hline M-6 & 17.0 & 880 & 16.7 & 3.1 & 508 & 600 \\
\hline M-7 & 30.0 & 930 & 10.9 & 1.0 & 896 & 340 \\
\hline M-8 & 20.0 & 930 & 10.9 & 1.5 & 597 & 510 \\
\hline M-9 (With Ni-based OC) & 20.0 & 930 & 10.9 & 1.9 & 598. & 509 \\
\hline M-10 (With Ni-based OC) & 30.0 & 930 & 10.9 & 1.2 & 900 & 338 \\
\hline \multicolumn{7}{|l|}{ PSA off-gas } \\
\hline PSA-1 & 86.2 & 880 & 18.6 & 2.7 & 666 & 457 \\
\hline PSA-2 & 82.8 & 880 & 18.6 & 2.8 & 640 & 476 \\
\hline PSA-3 & 50.0 & 880 & 18.6 & 4.6 & 387 & 788 \\
\hline PSA-4 & 30.0 & 880 & 18.6 & 7.6 & 232 & 1313 \\
\hline \multicolumn{7}{|l|}{ Syngas $\mathrm{CO} / \mathrm{H}_{2}=1$} \\
\hline$S-1$ & 73.0 & 880 & 16.9 & 2.9 & 713 & 427 \\
\hline$S-2$ & 54.2 & 880 & 16.9 & 3.9 & 529 & 575 \\
\hline$S-3$ & 36.5 & 880 & 16.9 & 5.7 & 357 & 853 \\
\hline \multicolumn{7}{|l|}{ Syngas $\mathrm{CO} / \mathrm{H}_{2}=3$} \\
\hline$S-4$ & 69.0 & 880 & 11.7 & 2.1 & 700 & 435 \\
\hline$S-5$ & 44.2 & 880 & 11.7 & 3.3 & 449 & 679 \\
\hline S-6 & 29.5 & 880 & 11.7 & 4.9 & 299 & 1018 \\
\hline
\end{tabular}

